\title{
Concentration of fungal metabolites, phenolic acids and metals in mixtures of cereals grown in organic and conventional farms
}

\author{
A. Ostrowska-Kołodziejczak ${ }^{1,4}$, K. Stuper-Szablewska', T. Kulik², M. Buśko', I. Rissmann', \\ M. Wiwart ${ }^{3}$ and J. Perkowski ${ }^{1}$ \\ ${ }^{1}$ Poznan University of Life Sciences, Department of Chemistry, Wojska Polskiego 28, 60-637 Poznań, Poland \\ University of Warmia and Mazury \\ ${ }^{2}$ Department of Botany and Nature Protection, pl. Łódzki 1, 10-719 Olsztyn, Poland \\ ${ }^{3}$ Department of Plant Breeding and Seed Production, Oczapowskiego 2, 10-719 Olsztyn, Poland
}

KEY WORDS: cereal mixtures, organic farming, trichothecenes, phenolic acids, heavy metals

Received: 6 February 2014

Revised: 30 November 2015

Accepted: 29 February 2016
${ }^{4}$ Corresponding author:

e-mail: anos@up.poznan.pl

\begin{abstract}
In view of expanding cultivation of cereal mixtures, the study was conducted to examine the effects of organic (ORG) vs conventional (CON) farming on fungal contamination, concentrations of phenolic acids (PA) and metals in mixtures of cereals grown in northern and central regions of Poland. The analyses were performed on $10 \mathrm{ORG}$ and $8 \mathrm{CON}$ bulk samples of oat, wheat and barley mixtures, each one comprised samples taken from 4 -5 farms. Fungal contamination was assessed as the concentration of ergosterol (ERG) and mycotoxins from trichothecene (TR) group, whereas the quantification of fungal species and TR genotypes was performed using TaqMan assay. Mean ERG content in grain produced in both systems was similar, although a markedly greater variation was recorded in ORG grain. Total TR mycotoxins concentration was, in both CON and ORG samples, low and comparable, however concentration of deoxynivalenol was considerably greater whereas that of 3-acetyl-deoxynivalenol (3-AcDON) and 15-AcDON and nivalenol were lower in ORG samples. Molecular analysis showed that the dominant fungi were Fusarium culmorum and F. graminearum. The Tri5 gene, a precursor of TR formation, was detected in significantly greater relative amounts in ORG samples. The ORG cereal mixtures contained greater total amounts of PA and, in particular, of gallic, p-cumaric and ferulic acids. Concentrations of $\mathrm{Cd}, \mathrm{Cu}$ and $\mathrm{Mg}$ did not differ between the ORG and CON cereals, whereas concentrations of $\mathrm{Fe}$, Se and $\mathrm{Zn}$ were greater in $\mathrm{CON}$, and those of $\mathrm{Mn}$ and $\mathrm{Pb}$ in ORG mixtures. The potentially hazardous substances were present in the samples of both CON and ORG cereal mixtures in concentrations which do not compromise the health of farm animals.
\end{abstract}

\section{Introduction}

Organic (ORG) farming is an alternative to the conventional $(\mathrm{CON})$ cultivation system providing farm products of high quality, referred to as organic (Maeder et al., 2002). The ORG farming in Poland is developing, as evidenced by the constantly growing number and acreage of ORG farms (Zdrojewska, 2013).

Cultivation of cereals in mixtures aims at the reduction of negative effects of pure stands, such as yield fluctuations, due to different adverse envi- 
ronmental conditions (Leszczyńska, 2007; Tratwal and Walczak, 2010). The world production of cereal mixtures is approximated for 4.8 million tons per year (FAO, 2009), with Poland being a dominant producer. In 2012, the area cropped to cereal mixtures in Poland was 1.45 million hectares, with north-eastern Poland being the leading region, followed by the central and eastern parts of the country (according to Agricultural Market Agency - ARR, Poland, 2013).

The most common cereal mixtures include barley and oat sown at a 1:1 ratio, or barley, wheat and oat sown at a 1:1:1 ratio. Proportions of harvested grain may differ since growth conditions adverse for one of the components, may be advantageous for another, which gains dominance in the stand and compensates for the potentially lower yield (Sobkowicz and Lejman, 2011). After harvesting, quality of grain in mixtures should be thoroughly monitored, since susceptibility to infestation the components by different pathogens is variable (Binder et al., 2007).

Microorganisms commonly found in grain include filamentous fungi, primarily those from the genera Aspergillus, Fusarium and Penicillium, responsible for the accumulation of mycotoxins in grain (Pasanen et al., 1999). Contamination of feeds with metabolites of filamentous fungi constitutes a serious health hazard, both for animals and humans. The trichothecenes (TR) are a group of mycotoxins produced by a variety of different Fusarium species. In Poland, the most common toxins are those from the group B of TR, e.g., deoxynivalenol (DON) and nivalenol (NIV) (Perkowski et al., 2012). The content of fungal toxins in grain is inseparably connected with the presence of mycobiota. In addition, content of ergosterol (ERG) is the marker of the presence of both live and dead mycobiota (Zhao et al., 2005).

Due to the fact that in the Poland's climatic zone the most toxigenic fungi are Fusarium culmorum and $F$. graminearum, the presence of these fungi and also of chemotypes 3-acetyl-deoxynivalenol (3-AcDON) and 15-acetyl-deoxynivalenol (15-AcDON) in grain is increasingly often analysed. Surveys from diverse geographic areas have revealed that distribution of chemotypes among local populations of $F$. graminearum $/ F$. culmorum varies and may change over time (Waalwijk et al., 2004). Rapid changes in the proportions of chemotypes within $F$. graminearum $/ F$. culmorum are difficult to predict because inoculum dispersal and development in this field is affected by complex factors. For this reason, quick identification of chemotypes is imperative in order to determine the potential risk to human and animal health (Pasquali et al., 2010).
As the marker of the potential capacity for TR production, the presence of the Tri5 gene, encoding trichodiene synthase involved in the first stage of the TR biosynthesis pathway, is assayed (Vegi and WolfHall, 2013).

Phenolic compounds and certain microelements, due to their antioxidant activity, significantly stimulate the plant resistance against fungal pathogens. The elevated concentration of ferulic acid, the most abundant acid among phenolic acids present in cereal grain, may indicate a more active plant response to the environmental stress (Lempereur et al., 1997). Selenium is a major microelement exhibiting antioxidant activity (Hartikainen and Xue, 1999). Also iron, magnesium, zinc, copper and manganese and trace elements like cadmium, lead and mercury are considered as important minerals affecting both the plant growth and grain nutritional value (Kawecka et al., 2013).

The aim of the study was to compare the fungi contamination levels in mixtures of cereals grown in ORG and CON farms, using the concentrations of ERG and mycotoxins from the TR group as a criteria. The results referred to molecular analyses in order to indicate dominant fungi found most commonly in the culture environment, and to determine the presence of the Tri5 gene responsible for the formation of TR in grain. The phenolic acids and selected metals contents were also determined.

\section{Material and methods}

\section{Material}

Cereal mixtures used in the study were grown in 2011 in the conventional and organic farms situated in ten communes of the two voivodeships in central (Kuyavian-Pomeranian and Greater Poland) and one in northern Poland (Warmian-Masurian Voivodeship) (Table 1).

The mixtures were composed of oat, wheat and barley sown in proportion $1: 1: 1$, grown under monitored temperature and precipitation conditions (Table 2), harvested at full ripeness using combine harvester and stored in grain silos. The analyses were performed on the bulk samples: 8 representing conventional and 10 organic farming. Each bulk

Table 1. Voivodeships and number of samples

\begin{tabular}{|c|c|c|c|c|}
\hline \multirow{2}{*}{ Voivodeship } & \multicolumn{2}{|c|}{ Conventional farming } & \multicolumn{2}{|c|}{ Organic farming } \\
\hline & bulk & individual & bulk & individual \\
\hline Kuyavian-Pomeranian & 2 & 9 & 2 & 9 \\
\hline Warmian-Masurian & 3 & 13 & 4 & 18 \\
\hline Greater Poland & 3 & 12 & 4 & 18 \\
\hline
\end{tabular}


Table 2. Values of mean temperature $\left({ }^{\circ} \mathrm{C}\right)$ and precipitation totals $(\mathrm{mm})$ in 2011 summer season (according to the Institute of Meteorology and Water Management - National Research Institute (Poland): http://www.imgw.pl/klimat/)

\begin{tabular}{|c|c|c|c|}
\hline \multirow{3}{*}{ Month } & \multicolumn{3}{|l|}{ Voivodeship } \\
\hline & $\begin{array}{l}\text { Kuyavian- } \\
\text { Pomeranian }\end{array}$ & $\begin{array}{l}\text { Warmian- } \\
\text { Masurian }\end{array}$ & $\begin{array}{l}\text { Greater } \\
\text { Poland }\end{array}$ \\
\hline & \multicolumn{3}{|c|}{ mean temperature, ${ }^{\circ} \mathrm{C} / /$ precipitation totals, $\mathrm{mm}$} \\
\hline May & $14 / / 30$ & $13 / / 50$ & $14 / / 30$ \\
\hline June & $18 / / 80$ & $17 / / 60$ & $18 / / 70$ \\
\hline July & $17 / / 140$ & $17 / / 180$ & $17 / / 140$ \\
\hline August & $18 / / 40$ & 17 // 60 & $18 / / 40$ \\
\hline
\end{tabular}

sample was made of individual samples collected in $4-5$ respective farms. The bulk samples were prepared in the laboratory, stored at $-20{ }^{\circ} \mathrm{C}$ till botanical and chemical analysis.

\section{Botanical analysis of mixtures}

The analysis of botanical composition was performed in three replications on $100 \mathrm{~g}$ of bulk samples. Wheat, barley and oat grains were separated by hand, weighed and their proportions in the harvested mixture were calculated.

\section{Chemical analysis}

Dry matter of the grain was determined using the AOAC International (2002) method No. 2001.12 for determination of water/dry matter (moisture) in animal feed, grain and forage (plant tissue). The results were expressed in relation to the dry matter content.

Ergosterol (ERG) concentration was determined after saponification and microwave extraction. After saponification ERG was extracted using pentane and evaporated to dryness in a gentle stream of a high purity nitrogen. Samples were dissolved in methanol and analysed using a high-performance liquid chromatography (Alliance 2695) with an absorptiometric diode detector (Photodiode Array Detector 2996). Chromatographic separation was performed on a Nova-Pak C18 column $(150 \mathrm{~mm} \times 3.9 \mathrm{~mm})$. This analysis was performed on the equitment provided by Waters Corporation (Milford, MA, USA). Methanol and acetonitrile mixture at a 90:10 ratio (v/v) was used as an eluent. ERG concentration was measured using an external standard at wavelength $\lambda=282 \mathrm{~nm}$. The compound was identified by comparing the retention time of the peak with the original standard and by adding a specific amount of the standard to the sample. The analysis was repeated. The limit of detection was $0.01 \mathrm{mg} \cdot \mathrm{kg}^{-1}$ (Perkowski et al., 2008).
Contents of trichothecenes from group B were determined following the extraction of the compounds with a acetonitrile-water mixture at a 82:18 ratio $(\mathrm{v} / \mathrm{v})$ and purification by solid-phase extraction on a charcoal column Mycosep ${ }^{\circledR} 225$ Trich (Romer Labs, Getzersdorf, Austria). The TR from group B were analysed as trimethylsilyl derivatives. Chromatographic separation and detection were conducted on equipment provided by Hewlett Packard (Waldbronn, Germany) using a gas chromatograph (GC 6890) equipped with a mass detector (MS $5972 \mathrm{~A}$ ) and capillary column (HP-5MS, $0.25 \mathrm{~mm} \times 30 \mathrm{~m}$ ). Analysis was performed in the selective ion monitoring mode (SIM). The selective ions for each examined compound were: deoxynivalenol (DON) 103 and 512, 3-acetyl-deoxynivalenol (3-AcDON) 117 and 482, 15-acetyl-deoxynivalenol (15-AcDON) 193 and 482, fusarenone X (FUS-X) 103 and 570, and for nivalenol (NIV) 191 and 600. Helium flow rate was $0.7 \mathrm{~cm}^{3} \cdot \mathrm{min}^{-1}$. In order to confirm the presence of investigated toxins in the sample, the analysis was performed over the entire mass range (100-700 unified atomic mass unit). Results were processed in the MS Chem Station programme (HP G1034A; Hewlett Packard, Waldbronn, Germany). Recovery for the analysed toxins was: DON $84 \pm 3.8 \%, 3$ AcDON $78 \pm 4.8 \%, 15 \mathrm{AcDON} 74 \pm 2.2 \%$, and NIV $81 \pm 3.8 \%$. The detection limit for the analysed toxins was $0.001 \mathrm{mg} \cdot \mathrm{kg}^{-1}$ (Perkowski et al., 2003).

Phenolic acids were determined after basic and than acid hydrolysis. Ground grain $(0.2 \mathrm{~g})$ was hydrolysed using $1 \mathrm{ml}$ of $\mathrm{H}_{2} \mathrm{O}$ and $4 \mathrm{ml}$ of $2 \mathrm{M} \mathrm{NaOH}$ followed by acid hydrolysis in $3 \mathrm{ml}$ of $6 \mathrm{M} \mathrm{HCl}$. Phenolic acids were extracted from the inorganic phase using diethyl ether. Extracts were evaporated to dryness in a gentle stream of a high purity nitrogen. Contents of phenolic acids were determined using a high-performance liquid chromatography (Alliance 2695) with a photodiode array detector (Photodiode Array Detector 2996) (both from Waters Corporation, Milford, MA, USA). Chromatographic separation was performed on a RP C-18 column $(250 \mathrm{~mm} \times 4 \mathrm{~mm} \times 5 \mu \mathrm{m}$; Waters, Ireland). A mixture of acetonitrile: $2 \%$ acetic acid in water $(\mathrm{pH}=2)$ was applied as the eluent (gradient). Measurements of phenolic acid concentrations were performed using an external standard at wavelengths $\lambda=320 \mathrm{~nm}$ and $\lambda=280 \mathrm{~nm}$. Compounds were identified on the basis of the comparison of retention times of the peaks with those of the standard and by adding a specific amount of the standard to the tested sample. The analyses were repeated. Retention times of analysed acids were as follows, min: gallic 8.85 , 
4-hydroxybenzoic 19.46, vanilic 24.11, caffeic 26.19, syringic 28.05 , p-cumaric 40.20 , synapic 48.00 . Limit of detection was $1 \mathrm{mg} \cdot \mathrm{kg}^{-1}$.

Metal analysis. The material was mineralized with a CEM Mars 5 Xpress (CEM, Matthews, NC, USA) microwave mineralization system $(55 \mathrm{ml}$ vessels) using $8 \mathrm{ml} \mathrm{HNO}_{3}(65 \%)$ and $2 \mathrm{ml} \mathrm{H}_{2} \mathrm{O}_{2}$, according to the programme comprising three stages: first stage - power $800 \mathrm{~W}$, time $10 \mathrm{~min}$, temperature $120^{\circ} \mathrm{C}$; second stage - power $1600 \mathrm{~W}$, time $10 \mathrm{~min}$, temperature $160{ }^{\circ} \mathrm{C}$; third stage-power $1600 \mathrm{~W}$, time $10 \mathrm{~min}$, temperature $200^{\circ} \mathrm{C}$. Materials after digestion were filtered through $45 \mathrm{~mm}$ filters (Qualitative Filter Papers Whatman, Grade 595: 4-7 $\mu \mathrm{m}$; GE Healthcare, Buckinghamshire, UK), and filtrate completed with deionized water from Milli-Q Academic System (non-TOC (Total Organic Carbon); Millipores. A.S., Molsheim, France) to a final volume of $50 \mathrm{ml}$. Concentration of particular trace elements was analysed by the flame atomic absorption spectrometry $(\mathrm{Cd}, \mathrm{Cu}, \mathrm{Fe}, \mathrm{Mn}, \mathrm{Pb}$ and $\mathrm{Zn})$, atomic emission spectrometry $(\mathrm{Mg})$ and hydride generous atomic absorption spectrometry (Se), using an AA Duo-AA280FS/AA280Z spectrometer (Agilent Technologies, Mulgrave, Victoria, Australia), equipped with a Varian hollow-cathode lamp (HCL; Varian, Mulgrave, Victoria, Australia). Calibration curves were prepared in four replicates per each trace element concentration. Detection limit for the analysed metals was, $\mathrm{ng} \cdot \mathrm{kg}^{-1}: \mathrm{Cd} 0.01$, $\mathrm{Cu}$ 0.18, Fe 0.11, Mg 0.003, Mn 0.005, Pb 0.14, Zn 0.06, Se 0.21 (Mleczek et al., 2010).

\section{Molecular analysis}

DNA extraction. Grain samples $(0.25 \mathrm{~g})$ were homogenized $\left(30 \mathrm{~s}\right.$ at speed $\left.6.0 \mathrm{~m} \cdot \mathrm{s}^{-1}\right)$ on a FastPrep-24 instrument in tubes with $1 \mathrm{~mm}$ silica spheres (Lysing matrix C) both provided by MP Biomedicals (Solon, OH, USA). Total DNA was extracted using a ChargeSwitch ${ }^{\circledR}$ gDNA Plant Kit following the manufacturer's recommendations (Invitrogen, Carlsbad, CA, USA).

TaqMan assays were used for quantification of F. culmorum, F. graminearum (Waalwijk et al., 2004), the Tri5 gene and 3AcDON, 15AcDON chemotypes (Kulik, 2011). A fungal DNA assay (Kulik, 2011) was used as an internal control in order to identify samples, for which the PCR or the DNA extraction failed. TaqMan reaction conditions were used for both species, TR genotypes and fungal internal positive control (IPC) in the modified fast PCR protocol: $95^{\circ} \mathrm{C}$ for $20 \mathrm{~s}$ and $\left(95^{\circ} \mathrm{C}\right.$ for $3 \mathrm{~s}, 60^{\circ} \mathrm{C}$ for $\left.30 \mathrm{~s}\right) \times 40$. For quantification of the Tri5 gene, a PCR protocol was used: $95^{\circ} \mathrm{C}$ for $10 \mathrm{~min}$ and $\left(95^{\circ} \mathrm{C}\right.$ for $15 \mathrm{~s}, 60^{\circ} \mathrm{C}$ for $1 \mathrm{~min}) \times 40$. TaqMan PCR mixture was composed of: $2 \mu 1$ DNA, $13 \mu 1 \mathrm{H}_{2} \mathrm{O}, 5 \mu \mathrm{l}$ TaqMan Fast Advanced Master Mix (Applied Biosystems, Foster City, CA, USA), $6 \mathrm{pM}$ of each primer and $1.7 \mathrm{pM}$ of probe. All PCR amplifications were carried out in a ViiA 7 Real-Time PCR System (Applied Biosystems, Foster City, CA, USA) in a final volume of $20 \mu \mathrm{l}$. The threshold value was 0.1 . To determine the efficiency and sensitivity of the assay, 21-36 ng of genomic DNA of $F$. culmorum/F. graminearum different isolates were serially diluted with water and used as a template. Amplification efficiencies for F. culmorum, F. graminearum, the Tri5 gene, $3 \mathrm{AcDON}$ and $15 \mathrm{AcDON}$ assays were $97 \%, 101.2 \%, 93 \%, 101.9 \%$ and $99.3 \%$, respectively. In order to eliminate falsepositive results, a PCR reaction was considered positive only if the cycle threshold $(\mathrm{Ct})$ value was $<35$.

\section{Statistical analysis}

Results of chemical analyses were subjected to a statistical analysis with the use of STATISTICA 8.0 software, 2014 (StatSoft Polska, Kraków, Poland). Contents of individual compounds in CON and ORG mixtures were compared using Tukey's multiple comparison procedure with significant differences at level $P=0.05$. An analysis of variance and assessment of the homogeneity of variance were determined. The least significant differences were determined by post-hoc LSD test. Linear regression between oat and ergosterol contents was calculated by Least Square method.

\section{Results and discussion}

Both mean temperature and precipitation values in May, June, July and August 2011 were very similar in the two central voivodeships (KuyavianPomeranian and Greater Poland) whereas in the north-eastern Warmian-Masurian Voivodeship total precipitations and particularly precipitations in July, were greater (Table 2).

The proportions of three cereals in bulk samples differed from the sown ratio but were similar in CON and ORG mixtures. Proportions of oat varied from 26 to $33 \%$ and from 23 to $30 \%$, of wheat from 34 to $43 \%$ and from 28 to $40 \%$, and those of barley from 28 to $39 \%$ and from 31 to $40 \%$ in CON and ORG samples, respectively (Table 3 ).

The recorded ERG concentration was relatively low and did not differ significantly between mixtures from CON and ORG farms (8.77 vs $7.94 \mathrm{mg} \cdot \mathrm{kg}^{-1}$; Table 4). However, whereas the ERG content in 
Table 3. Botanical composition of cereal mixture, \%

\begin{tabular}{|c|c|c|c|c|c|c|c|}
\hline \multirow{2}{*}{$\begin{array}{l}\text { No. } \\
\text { of sample }\end{array}$} & \multicolumn{3}{|c|}{ Conventional farming } & \multirow{2}{*}{$\begin{array}{l}\text { No. } \\
\text { of sample }\end{array}$} & \multicolumn{3}{|c|}{ Organic farming } \\
\hline & oat & wheat & barley & & oat & wheat & barley \\
\hline 1 & 30 & 34 & 36 & 9 & 32 & 28 & 40 \\
\hline 2 & 33 & 35 & 32 & 10 & 30 & 39 & 31 \\
\hline 3 & 29 & 40 & 31 & 11 & 29 & 32 & 39 \\
\hline 4 & 31 & 38 & 31 & 12 & 32 & 37 & 31 \\
\hline 5 & 31 & 35 & 34 & 13 & 27 & 40 & 33 \\
\hline 6 & 26 & 40 & 34 & 14 & 30 & 36 & 34 \\
\hline 7 & 27 & 34 & 39 & 15 & 25 & 38 & 37 \\
\hline \multirow[t]{3}{*}{8} & 29 & 43 & 28 & 16 & 28 & 37 & 35 \\
\hline & & & & 17 & 23 & 38 & 39 \\
\hline & & & & 18 & 31 & 35 & 34 \\
\hline
\end{tabular}

Table 4. Mean concentrations of ergosterol (ERG) and trichothecenes in mixtures of cereals grown in conventional (CON) and organic (ORG) farms

\begin{tabular}{|c|c|c|c|c|c|c|c|c|}
\hline \multirow{2}{*}{$\begin{array}{l}\text { Cultivation } \\
\text { system }\end{array}$} & \multirow{2}{*}{$n$} & \multirow{2}{*}{$\begin{array}{l}\text { ERG, } \\
\mathrm{mg} \cdot \mathrm{kg}^{-1}\end{array}$} & \multicolumn{5}{|c|}{ Trichothecenes $^{1}, \mu \mathrm{g} \cdot \mathrm{kg}^{-1}$} & \multirow{2}{*}{ Tota } \\
\hline & & & $\overline{\mathrm{DON}}$ & FUS-X & 3-AcDON & 15-AcDON & NIV & \\
\hline $\mathrm{CON}$ & 8 & 8.77 & $12.5^{b}$ & 1.0 & $2.8^{\mathrm{a}}$ & $4.3^{a}$ & $9.8^{\mathrm{a}}$ & 30.4 \\
\hline ORG & 10 & 7.94 & $21.2^{\mathrm{a}}$ & 0.9 & $0.7^{\mathrm{b}}$ & $2.4^{\mathrm{b}}$ & $5.3^{b}$ & 30.5 \\
\hline
\end{tabular}

${ }^{1}$ DON - deoxynivalenol, FUS-X - fusarenone X, 3-AcDON - 3-acetyl-deoxynivalenol, 15-AcDON - 15-acetyl-deoxynivalenol, NIV - nivalenol; ab - means with different superscripts within column are significantly different at $P<0.05$

CON mixtures was fairly uniform, in ORG mixtures about tenfold differences between samples No. 10 and 17 vs 12 were found (Figure 1). The greater variability of ERG concentration in ORG mixtures could be the effect of a probably less uniform cultivation measures and, consequently, plants' growing conditions under this system. Since there is no data available on the fungal contamination of grain in cereal mixtures, the results of present study were compared with the reported contamination of respective cereals grown in pure stands. Stuper and Perkowski (2008) found that the colonization of barley, wheat and oat grain by mycobiota was variable. In their study the mean ERG content in wheat,

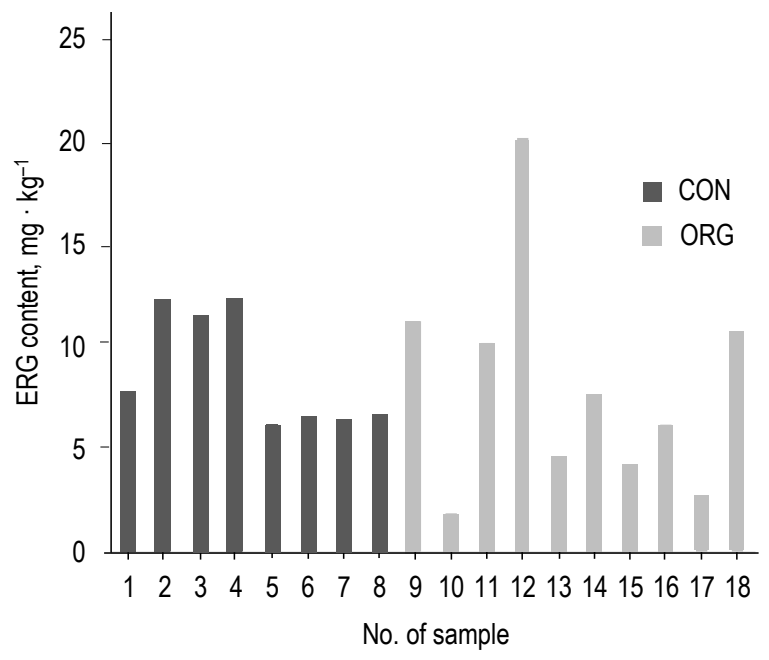

Figure 1. Ergosterol (ERG) content in mixtures of cereals grown in conventional (CON) and organic (ORG) farms barley and oat was $4.13,9.21$ and $16.11 \mathrm{mg} \cdot \mathrm{kg}^{-1}$, respectively. When these values were applied to the cereals present in the mixture in mean proportion of 37:34:29, respectively, the calculated approximate ERG concentration of $9.3 \mathrm{mg} \cdot \mathrm{kg}^{-1}$ is very close to the analysed values.

The correlation analysis between the ERG contents and proportions of wheat, barley and oat in the analysed mixtures showed that concentration of ERG is positively correlated with proportion of oat. The respective correlation formula is:

$$
\mathrm{y}=1.113 \mathrm{x}-24.04(\mathrm{r}=0.671, P=0.05)
$$

where: $\mathrm{y}$ - concentration of ERG $\left(\mathrm{mg} \cdot \mathrm{kg}^{-1}\right)$, $\mathrm{x}$ - weight percent of oat in cereal mixtures (\%).

This finding is in agreement with the results of Stuper and Perkowski (2008) and may indicate greater susceptibility of oat to fungal contamination and, in consequence, greater mycobiota concentration in the mixture with a higher proportion of oat.

The presence of mycotoxins in grain is strictly related to the content of toxigenic fungi in the agricultural environment. In Poland, the most common toxins are those from the TR group including DON and NIV (Perkowski et al., 2012). Wiśniewska and Buśko (2005) found also a strong and statistically significant correlation between DON and ERG content $(r=0.91)$. Mixtures grown in the CON farms were less contaminated with DON but more contaminated with its derivatives 3-AcDON and 15-AcDON, and NIV (Table 4). Concentrations of fusarenone $\mathrm{X}$ (FUS-X) and total toxins did not differ between 


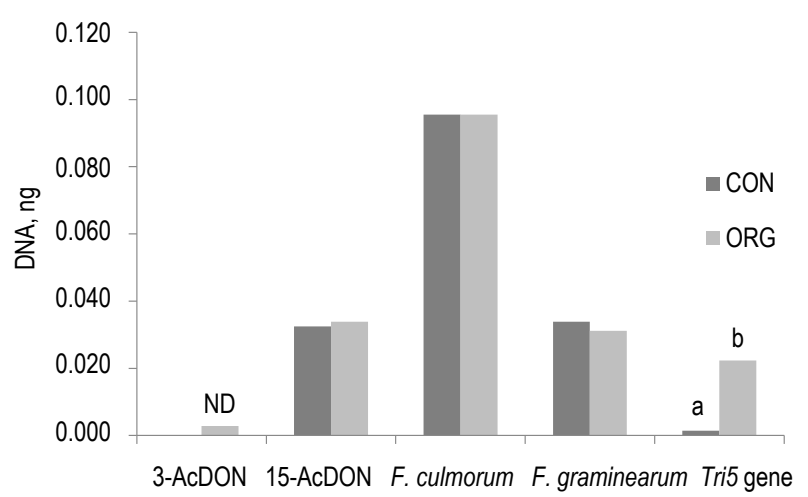

Figure 2. Quantification of chemotypes: 3-acetyl-deoxynivalenol (3-AcDON) and 15-acetyl-deoxynivalenol (15-AcDON), fungi: Fusarium culmorum and $F$. graminearum and Tri5 gene in grain of cereal mixtures from conventional (CON) and organic (ORG) cultivation systems (identification based on genetic analyses); ${ }^{a b}$ - bars with different superscripts are significantly different at $P<0.05$ for each examined parameter separately; ND - not detected

mixtures grown under the two farming systems. Concentration of DON in the analysed samples was considerably lower than the highest admissible level set by the regulations of EU (EC 1881/2006) for $1750 \mu \mathrm{g} \cdot \mathrm{kg}^{-1}$. Moreover, the concentrations of toxins found in present study are lower than those reported in cereals grown in the same period in Europe. Šliková et al. (2013) found that the mean content of DON in wheat grain collected in 2011 was $300 \mu \mathrm{g} \cdot \mathrm{kg}^{-1}$. The similar concentration of TR was also found by Fredlund et al. (2013) in oat.

Following the analysis of individual toxins, the presence of the toxigenic fungi species and chemotypes, and of Tri5 gene, was verified. The presence of chemotype 15-AcDON, reported in Poland for the first time in 1990 by Perkowski (1990), was found in all samples and did not differ between the ORG and CON mixtures (Figure 2). The 3-AcDON chemotype was present in minute amounts in ORG and was not detected in CON samples. The presence of F. culmorum was confirmed in all samples in concentrations similar for the two systems whereas $F$. graminearum was detected almost in all samples and in smaller amounts than F. culmorum. The Tri5 gene (ng DNA) was the only parameter which was affected by farming system and was greater in ORG than CON mixtures. This finding is in agreement with considerably greater DON concentration in ORG mixtures (21.2 vs $12.5 \mu \mathrm{g} \cdot \mathrm{kg}^{-1}$ ) but disagrees with smaller concentrations of other TR toxins. Up to our knowledge, no data on this topic is available in the literature and the effects of farming system on the concentrations of toxins and results of molecular analysis of respective fungi need more extensive studies.

Total phenolic acids concentration was considerably greater in grain from ORG than CON mixtures (Table 5). Among particular acids significantly greater were concentrations of gallic, p-cumaric and ferulic acids. Similar results were reported by Zuchowski et al. (2011) who found that concentrations of total and ferulic acids were greater in grain of spring wheat cultivated in ORG than in CON farms. Since phenolic acids are synthesized by plants in response to different types of stress (Robbins, 2003), their greater concentration may indicate that due to the lower mineral fertilization and lack of chemical protection under organic system, plants respond to the environmental stress in the enhanced manner.

The effects of farming system on the concentration of minerals were irregular (Table 6). Concentrations of iron, selen and zinc were smaller and those of manganese and lead were greater in ORG than in CON mixtures whereas concentrations of cadmium, copper and magnesium did not differ significantly. The lower iron concentration in ORG than CON mixtures is in agreement with the results of Ryan et al. (2004) on the effect of farming system on the content of this element in wheat. In our study, the concentrations of minerals were either slightly lower (magnesium, zinc), grater (iron) or similar (manganese, copper) to those found by Suchowilska et al. (2012) in the conventionally cultivated wheat.

Table 5. Mean concentrations of phenolic acids in mixtures of cereals grown in conventional (CON) and organic (ORG) farms

\begin{tabular}{|c|c|c|c|c|c|c|c|c|c|c|c|}
\hline \multirow{2}{*}{$\begin{array}{l}\text { Cultivation } \\
\text { system }\end{array}$} & \multirow{2}{*}{$\mathrm{n}$} & \multirow{2}{*}{ gallic } & \multicolumn{9}{|c|}{ Phenolic acids, $\mathrm{mg} \cdot \mathrm{kg}^{-1}$} \\
\hline & & & hydroxylbenzoic & chlorogenic & caffeic & siringic & vanilin & p-cumaric & ferulic & synapic & total \\
\hline CON & 8 & $20^{b}$ & 10 & 12 & 31 & 31 & 6 & $45^{b}$ & $1191^{b}$ & 20 & $1366^{b}$ \\
\hline ORG & 10 & $43^{a}$ & 19 & 11 & 31 & 36 & 27 & $66^{a}$ & $1989^{a}$ & 27 & $2249^{a}$ \\
\hline
\end{tabular}

ab - means with different superscripts within column are significantly different at $P<0.05$

Table 6. Mean concentrations of mineral compounds in mixtures of cereals grown in conventional (CON) and organic (ORG) farms

\begin{tabular}{lrllllllll}
\hline $\begin{array}{l}\text { Cultivation } \\
\text { system }\end{array}$ & $\mathrm{n}$ & \multicolumn{8}{l}{ Mineral compounds, $\mathrm{mg} \cdot \mathrm{kg}^{-1}$} \\
\cline { 3 - 11 } & & $\mathrm{Cd}$ & $\mathrm{Cu}$ & $\mathrm{Fe}$ & $\mathrm{Mg}$ & $\mathrm{Mn}$ & $\mathrm{Pb}$ & $\mathrm{Se}$ & $\mathrm{Zn}$ \\
\hline CON & 8 & 0.10 & 3.96 & $76.77^{\mathrm{a}}$ & 1261.00 & $29.69^{\mathrm{b}}$ & $0.034^{\mathrm{b}}$ & $0.28^{\mathrm{a}}$ & $27.48^{\mathrm{a}}$ \\
ORG & 10 & 0.09 & 5.16 & $54.63^{\mathrm{b}}$ & 1339.00 & $35.86^{\mathrm{a}}$ & $0.052^{\mathrm{a}}$ & $0.19^{\mathrm{b}}$ & $18.96^{\mathrm{b}}$ \\
\hline
\end{tabular}

ab - means with different superscripts within column are significantly different at $P<0.05$ 
The cadmium concentration in the mixtures was high and not affected by cultivation system which is against the suggested effects of cadmium on the plant resistance to fungal diseases (Zhang et al., 2008). The high concentration of cadmium in grain, in spite of its generally low content in Polish soils, may be due to soil sacidification and greater bioavailability of this element. Concentration of cadmium in both ORG and CON mixtures was reaching the upper limit amounting $0.10 \mathrm{mg} \cdot \mathrm{kg}^{-1}$ specified by EU (EC 1881/2006).

\section{Conclusions}

Organic cultivation of mixture of wheat, barley and oat increases variability of ergosterol concentration, does not affect the total content but differently affects particular trichothecenes contents (increases deoxynivalenon), and increases Tri5 gene. Ergosterol concentration in the mixture seems to be positively related to the proportion of oat. Organic cultivation stimulates the phenolic acids synthesis and has varied effect on concentration of minerals.

It may be concluded that the fungal contamination of the mixture of cereals cultivated accordingly to organic system is only slightly different from the contamination of the mixture of cereals grown conventionally and does not implicate a health hazard for animals.

\section{References}

Agricultural Market Agency - ARR (Poland), 2013. http://www.arr.gov. pl/data/00321/rynek_zboz_2013_pl.pdf

AOAC International, 2002. Official Methods of Analysis of AOAC International. $17^{\text {th }}$ Edition. $1^{\text {st }}$ Revision. Gaithersburg, MD (USA)

Binder E.M., Tan L.M., Chin L.J., Handl J., Richard J., 2007. Worldwide occurrence of mycotoxins in commodities, feeds and feed ingredients. Anim. Feed Sci. Tech. 137, 265-282

EU, 2006. Commission Regulation (EC) No 1881/2006 of 19 December 2006 setting the maximum levels for certain contaminants in foodstuffs

FAO, 2009. The state of food and agriculture. Livestock in the balance. Rome, pp. 109-119

Fredlund E., Gidlund A., Sulyok M., Börjesson T., Krska R., Olsen M., Lindblad M., 2013. Deoxynivalenol and other selected Fusarium toxins in Swedish oats - occurrence and correlation to specific Fusarium species. Int. J. Food Micobiol. 167, 276-283

Hartikainen H., Xue T., 1999. The promotive effect of selenium on plant growth as triggered by ultraviolet irradiation. J. Environ. Qual. 28, 1372-1375

Institute of Meteorology and Water Management - National Research Institute (Poland). http://www.imgw.pl/klimat/
Kawecka W., Rychlik E., Rachtan-Janicka J., Wrońska A., 2013. Presence of cadmium and lead in vegetables and crops from conventional and organic cultivation (in Polish). J. Ecol. Health $17,18-21$

Kulik T., 2011. Development of TaqMan assays for 3ADON, 15ADON and NIV Fusarium genotypes based on Tri12 gene. Cereal Res. Commun. 39, 200-214

Lempereur I., Rouau X., Abecassis J., 1997. Genetic and agronomic variation in arabinoxylan and ferulic acid contents of durum wheat (Triticum durum L.) grain and its milling fractions. J. Cereal Sci. 25, 103-110

Leszczyńska D., 2007. State and conditions of cultivation of grain crops mixtures in Poland (in Polish). J. Res. Appl. Agr. Eng. 52, 105-108

Maeder P., Fliessbach A., Dubois D., Gunst L., Fried P., Niggli U., 2002. Soil fertility and biodiversity in organic farming. Science 296, 1694-1697

Mleczek M., Kaczmarek Z., Magdziak Z., Golinski P.K., 2010. Hydroponic estimation of heavy metal accumulation by different genotypes of Salix. J. Environ. Sci. Health A Tox. Hazard. Subst. Environ. Eng. 45, 569-578

Pasanen A.-L., Yli-Pietilä K., Pasanen P., Kalliokoski P., Tarhanen J., 1999. Ergosterol content in various fungal species and biocontaminated building materials. Appl. Environ. Microbiol. 65, 138-142

Pasquali M., Giraud F., Brochot C., Cocco E., Hoffmann L., Bohn T., 2010. Genetic Fusarium chemotyping as a useful tool for predicting nivalenol contamination in winter wheat. Int. J. Food Microbiol. 137, 246-253

Perkowski J., Buśko M., Stuper K., Kostecki M., Matysiak A., Szwajkowska-Michałek L., 2008. Concentration of ergosterol in small-grained naturally contaminated and inoculated cereals. Biologia 63, 542-547

Perkowski J., Kiecana I., Kaczmarek Z., 2003. Natural occurrence and distribution of Fusarium toxins in contaminated barley cultivars. Eur. J. Plant Pathol. 109, 331-339

Perkowski J., Plattner R.D., Goliński P., Vesonder R.F., Chelkowski J., 1990. Natural occurrence of deoxynivalenol, 3-acetyl-deoxynivalenol, 15-acetyl-deoxynivalenol, nivalenol, 4,7-dideoxynivalenol and zearalenone in Polish wheat. Mycotoxin Res. $6,7-12$

Perkowski J., Stuper K., Buśko M., Góral T., Jeleń H., Wiwart M., Suchowilska E., 2012. A comparison of contents of group A and $B$ trichothecenes and microbial counts in different cereal species. Food Addit. Contam. B Surveill. 5, 151-159

Robbins R.J., 2003. Phenolic acids in foods: an overview of analytical methodology. J. Agr. Food Chem. 51, 2866-2887

Ryan M.H., Derrick J.W., Dann P.R., 2004. Grain mineral concentrations and yield of wheat grown under organic and conventional management. J. Sci. Food Agric. 84, 207-216

Sobkowicz P., Lejman A., 2011. The effect of multispecies cereal mixtures on weed infestation with annual species (in Polish). Progr. Plant Prot. 51, 478-481

Stuper K., Perkowski J., 2008. Content of ergosterol in food products of cereal (in Polish). Żywn. Nauk. Technol. Ja. 60, 71-77

Suchowilska E., Wiwart M., Kandler W., Krska R., 2012. A comparison of macro- and microelement concentrations in the whole grain of four Triticum species. Plant Soil Environ. 58, 141-147

Šliková S., Gavurníková S., Šudyová V., Gregová E., 2013. Occurrence of deoxynivalenol in wheat in Slovakia during 2010 and 2011. Toxins 5, 1353-1361 
Tratwal A., Walczak F., 2010. Powdery mildew (Blumeria graminis) and pest occurrence reduction in spring cereal mixtures. J. Plant Prot. Res. 50, 402-407

Vegi A., Wolf-Hall C.E., 2013. Multiplex Real-Time PCR method for detection and quantification of mycotoxigenic fungi belonging to three different genera. J. Food Sci. 78, M70-M76

Waalwijk C., van der Heide R., de Vries I. et al., 2004. Quantitative detection of Fusarium species in wheat using TaqMan. Eur. J. Plant Pathol. 110, 481-494

Wiśniewska H., Buśko M., 2005. Evaluation of spring wheat resistance to Fusarium seedling blight and head blight. Biologia 60, 287-293

Zdrojewska I., 2013. Statistical data concerning organic farming in Poland in the years 2011-2012 (in Polish). In: Report on the Condition of Organic Agriculture in Poland in the Years 2011-2012. Inspekcja Jakości Handlowej Artykułów RolnoSpożywczych. Warszawa (Poland), pp. 19-26
Zhang G., Fukami M., Sekimoto H., 2008. Genotypic differences in effects of cadmium on growth and nutrient compositions in wheat. J. Plant Nutr. 23, 1337-1350

Zhao X.R., Lin Q., Brookes P.C., 2005. Does soil ergosterol concentration provide a reliable estimate of soil fungal biomass? Soil Biol. Biochem. 37, 311-317

Zuchowski J., Jonczyk K., Pecio L., Oleszek W., 2011. Phenolic acid concentrations in organically and conventionally cultivated spring and winter wheat. J. Sci. Food Agric. 91, 1089-1095 